\title{
Muhammadiyah dan Politik: \\ Dilema Antara Keep Close dan Keep Distance
}

\section{Muhammadiyah and Politics: \\ The Dilemma Between 'Keep Close' and 'Keep Distance'}

\author{
Ma'mun Murod Al-Barbasy \\ Pusat Studi Islam dan Pancasila (PSIP) Universitas Muhammadiyah Jakarta \\ Jl. KH. Ahmad Dahlan Cirendeu Ciputat Jakarta Selatan 15419 \\ E-mail: mamunmurod73@gmail.com
}

\begin{abstract}
Abstrak: Muhammadiyah dilahirkan bukan sebagai organisasi politik. Namun karena dominasi perspektif di Muhammadiyah yang menganggap Islam sebagai agama dan juga Negara, maka praktis sejak kelahirannya hingga saat ini Muhammadiyah tak mampu melepas sepenuhnya dalam relasinya dengan politik. Dalam relasinya dengan politik, Muhammadiyah selalu mengalami pasang surut, yang dapat ditilik dari sejarah perjalanan panjang Muhammadiyah sejak lahir pada tahun 1912 hingga saat ini. Adakalanya mencoba untuk menjauh dari kekuasaan dengan berusaha menjaga jarak yang sama, namun adakalanya berusaha mendekat dengan berusaha menjaga kedekatan yang sama dengan semua kekuatan politik yang ada.
\end{abstract}

Kata Kunci: menjaga jarak, mendekat, khittah

\begin{abstract}
Although not born as a political organization, Muhammadiyah organization until now could not detach itself completely from politics. This is due to the fact that many members of the Muhammadiyah organization have a perspective that Islam is both religion and state. Since its birth in 1912, Muhammadiyah organization has experienced up and down relations with political power. With the spirit of "keep close" and "keep distance", it sometimes approached the political power and at another time it tried hardly to get away from it.

Keywords: keep close, keep distance, khittah
\end{abstract}

\section{A. Pendahuluan}

Membincang relasi Muhammadiyah dan politik tak akan ada habisnya. Sejak kelahirannya hingga saat ini selalu saja menarik untuk dibincangkan. Dan perbincangan ini biasanya lebih menarik ketika jelang hingga pasca 
perhelatan-perhelatan politik, baik di lingkup nasional maupun lokal, seperti pemilu legislatif, pemilu presiden, dan pemilihan kepala daerah. Perbincangan ini juga akan semakin hangat bila kenyataan politik menunjukkan bahwa "wakil-wakil" Muhammadiyah tidak cukup terepresentasikan duduk dalam jabatan-jabatan politik, baik di lingkup eksekutif, legislatif, maupun jabatan publik lainnya.

Tentu tidak salah membincang relasi Muhammadiyah dan politik, karena meskipun kelahiran Muhammadiyah tidak dikonstruks sebagai organisasi politik atau partai politik, namun faktanya Muhammadiyah telah memposisikan diri sebagai "gerakan politik". Penyebutan ini sebenarnya hanya salah satu dari sekian banyak pelebelan yang disematkan pada Muhammadiyah. Muhammadiyah sendiri tegas menyebut dirinya sebagai gerakan Islam dan dakwah amar makruf nahi munkar, yang beraqidah Islam dan bersumber pada al-Qur'an dan Sunah. ${ }^{1}$

Sejarah mencatat, Muhammadiyah lahir dalam situasi sarat politik, baik konteks politik keagamaan terkait "pertarungan" perebutan pengaruh keagamaan di antara kekuatan keagamaan yang terjadi di dunia Islam (Jazirah Arab) dan Nusantara saat itu, maupun politik dalam arti perlawanan terhadap kolonial Belanda. Pertarungan keagamaan ini kemudian merembet kepada pertarungan politik seiring runtuhnya Khilafah Usmaniyah Turki pada Februari $1924 .^{2}$ Terjadi perebutan pengaruh di antara raja-raja di Jazirah Arab yang mencoba menghidupkan kembali khilafah dan menyandangnya gelar khalifah. Tercatat ada tiga raja yang saling berebut pengaruh untuk menghidupkan kembali khilafah Islamiyah, yaitu Raja Hijaz Syarif Hussein, ${ }^{3}$ Raja ibnu Sa'ud dari Najed (sekarang Arab Saudi), yang juga musuh besar Hussein, ${ }^{4}$ dan Raja Fuad dari Mesir. ${ }^{5}$ Kecenderungan di Jazirah Arab untuk menghidupkan kembali Khilafah Islamiyah sebenarnya lebih banyak disebabkan oleh kekecewaannya pada Khilafah Utsmaniyah yang sering menafikan orang-orang Arab. ${ }^{6}$ 
Menyikapi realitas ini, menuntut Muhammadiyah untuk bersikap. Sejak awal, Muhammadiyah lebih condong kepada Kongres Mesir. Sementara Sarekat Islam (SI) dan Tashwirul Afkar, ${ }^{7}$ lebih menghendaki Kongres Makkah. Walau keduanya -SI dan Tashwirul Afkar- mempunyai alasan yang berbeda, tapi keduanya menganggap bahwa masalah pembaharuan lebih penting daripada sekedar membahas masalah khilafah. Karena tidak mencapai kata sepakat, permasalahan tersebut dibawa ke Kongres Al-Islam III Desember $1924 . .^{8}$

Kelahiran Muhammadiyah juga dipengaruhi oleh faktor internal terkait dengan ketakmurnian ajaran Islam, yang masih tercampur tradisi Hindu, Budha, anismisme dan dinamisme. Sinkretisme dalam tradisi keberagamaan dalam Islam masih begitu menonjol. Junus Salam ${ }^{9}$ menyebut bahwa kelahiran Muhammadiyah didorong oleh dan atas pergumulannya dalam menghadapi kenyataan hidup umat Islam dan masyarakat Indonesia kala itu, yang juga menjadi tantangan untuk dihadapi dan dipecahkan. Ada faktor-faktor yang menjadi pendorong lahirnya Muhammadiyah, di antaranya umat Islam tidak memegang teguh al-Quran dan Sunnah, sehingga menyebabkan merajalelanya syirik, bid'ah, dan khurafat; ketiadaan persatuan di antara umat Islam, akibat tak tegaknya ukhuwah Islamiyah serta ketiadaan suatu organisasi yang kuat; kegagalan sebagian lembagalembaga pendidikan Islam dalam menghasilkan kader-kader Islam, karena tak lagi dapat memenuhi tuntutan jaman; umat Islam kebanyakan hidup dalam fanatisme sempit, taklid buta serta berpikir dogmatis, berada dalam konservatisme, formalisme, dan tradisionalisme; dan karena keinsyafan akan bahaya yang mengancam kehidupan dan pengaruh Islam, serta berhubung dengan misi dan zending Kristen di Indonesia yang semakin menanamkan pengaruhnya di kalangan rakyat.

Selain itu, juga semakin meningkatnya gerakan Kristenisasi. Belanda masuk ke Indonesia mengibarkan panji “3 G” (Glory, Gold, dan Gospel). Glory 
dominan terkait motif politik. Gold terkait faktor ekonomi, kekayaan untuk mengeruk kekayaan Indonesia. Gospel, terkait motif agama, penyebaran keyakinan, motif untuk mengubah keyakinan orang lain. ${ }^{10}$ Tiga Disertasi yang ditulis oleh Deliar Noer, ${ }^{11}$ Alfian, ${ }^{12}$ dan Alwi Shihab ${ }^{13}$ bicara banyak terkait misi Belanda dalam melakukan Kristenisasi di Indonesia.

Sumbangsih Belanda terhadap misi Kristen di Indonesia luar biasa. Kiai Dahlan peduli dalam mengantisipasi Kristenisasi, tapi caranya cukup cerdas dan elegan, dengan mengajak diskusi terbuka sejumlah pendeta. Kiai Dahlan mendorong umat Islam untuk mengkaji semua agama guna menemukan kebenaran yang dinilai paling hakiki. Kiai Dahlan bahkan beranggapan bahwa diskusi-diskusi tentang Kristen boleh dilakukan di masjid. ${ }^{14}$ Dikisahkan bahwa sekolah-sekolah yang didirikan Kiai Dahlan dengan sistem kelas, di antara guru-gurunya juga terdapat yang non-Muslim. Guru-guru non-muslim ini diminta untuk mengajar pelajaran bahasa asing, ilmu hukum, dan wawasan Internasional. ${ }^{15}$

Penetrasi bangsa Eropa, terutama dalam bidang politik, juga terlihat secara kasat mata. Islam dikutubkan pada dua kutub ekstrim, yaitu antara "Islam politik" dan "Islam ibadah". Pengkutuban ini atas petunjuk Snouck Horgronje. ${ }^{16}$ Terhadap Islam ibadah, Belanda diminta toleran, tampak begitu akomodatif, dalam beberapa hal bahkan mendukung untuk tumbuh pesat. Bahkan ini menjadi syarat yang tak boleh tidak harus diwujudkan demi stabilitas, seperti mendirikan tempat ibadah, kegiatan keagamaan, menunaikan ibadah haji dan menjalankan puasa. Sementara terhadap Islam politik, Belanda diminta tidak toleran sama sekali, bahkan harus ditekan. Musuh Belanda bukanlah "Islam ibadah", tapi "Islam politik". Terhadap "Islam politik", rezim selalu memandang penuh curiga. Gerakan-gerakan politik umat Islam selalu dilihatnya sebagai kelompok ekstrim atau radikal. ${ }^{17}$ Ini menjadi doktrin politik Belanda selama menjajah Indonesia. Doktrin ini 


\section{MUHAMMADIYAH DAN POLITIK}

tanpa sadar selalu diterapkan berulang sejak Indonesia merdeka sampai saat ini.

Sementara terkait politik, meskipun tak pernah secara mandiri menjadi partai politik, namun dalam sejarahnya Muhammadiyah tak pernah bisa lepas dari urusan politik, tentu politik dalam pengertian nilai, bukan ansich kekuasaan. Pada masa penjajahan Belanda, ketika di satu sisi harus menegakkan Islam berkemajuan, sementara di sisi lain berhadapan dengan Belanda, Muhammadiyah secara cerdas berhasil memanfaatkan institusiinstitusi penjajah untuk dijadikan sebagai sarana bagi upaya mencerdaskan masyarakat.

Pendekatan ini berbeda dengan gerakan atau organisasi keagamaan lainnya, yang menolak bekerjasama dengan Belanda, termasuk menerapkan model pendidikan khas penjajah sebagai sarana pencerdasan masyarakat. Alfian menyebut bahwa strategi yang dipakai Muhammadiyah dalam memasarkan model Islam berkemajuan sebagai bentuk pemahaman Islam yang toleran (tasamuh) dan moderat (tawasuth) dari Kiai Dahlan terhadap kaum non-Muslim. Kiai Dahlan juga dikenal sebagai kiai yang tepo seliro. Kiai Dahlan misalnya menjalin hubungan dekat dengan KH. Hasyim Asy'ari (NU). ${ }^{18}$ Juga bersahabat dengan KH. Misbach (PKI), dan berkawan dengan beberapa orang Ahmadiyah.

Sikap Kiai Dahlan ini menjadi pijakan politik Muhammadiyah. Tentu politik di sini dipahami dalam dinamika relasi antara paham keagamaan Muhammadiyah dengan realitas politik yang terjadi di jamannya. Muhammadiyah misalnya pernah menunjukkan sikap akomodatifnya terhadap Belanda, namun juga bisa bersikap anti-Belanda, seperti ditunjukkan saat Belanda mulai memperlakukan dan bersikap negatif terhadap Islam. Muhammadiyah juga mengkritik Ordonansi Guru dan ordonansi lainnya, terlebih yang mencampuri urusan umat Islam. 19 Muhammadiyah menemukan sejumlah sikap Belanda yang diskriminatif dan 
anti Islam, seperti dukungan Belanda, terutama dalam hal pemberian subsidi yang begitu besar kepada Kristen, bila dibandingkan dengan misalnya, subsidi yang diterima Muhammadiyah. ${ }^{20}$

Penyebab posisi Muhammadiyah yang selalu bersinggungan dengan politik, bisa karena mencoba menghimpitkan diri dengan politik atau juga sebaliknya, karena realitas politik yang kerap memaksa dan menuntut Muhammadiyah harus menghimpitkan diri dengan politik. Inilah yang menyebabkan Muhammadiyah selalu saja tidak bisa lepas dari politik. Posisi politik seperti ini, kerap memunculkan dilema bagi Muhammadiyah. Sehingga, relasi Muhammadiyah dan politik pun kerap berlangsung tidak ajeg dan penuh dinamika. Terkadang relasi yang dibangunnya mencoba menjaga jarak (keep close) yang sama dengan semua kekuatan politik yang ada, namun ada kalanya pula mencoba menjaga kedekatan yang sama (keep distance) dengan semua kekuatan politik yang ada. Bahkan pada periode 1947-1959, Muhammadiyah pernah menjadi bagian yang tak terpisahkan dan menempati posisi yang cukup penting dalam Partai Masyumi. ${ }^{21}$

\section{B. Gerakan Politik Muhammadiyah}

Muhammadiyah lahir tidak dikonstruks sebagai organisasi politik atau partai partai, tapi sebatas sebagai "gerakan politik", tentu saja selain sebagai gerakan dakwah amar makruf nahi munkar. Konstruks sebagai "gerakan politik" tergambar dari langkah-langkah yang dilakukan Kiai Dahlan di awal-awal berdirinya, yang juga menjalin relasi politik dengan banyak pihak.

Selama periode 1912-1926, Muhammadiyah tegas menyebut diri bukan sebagai organisasi politik. Meskipun tidak dapat dipungkiri bahwa guratan-guratan wajah politik Muhammadiyah tampak begitu nyata. Tercatat, KH. Ahmad Dahlan termasuk sosok yang sangat dekat dengan Budi Utomo, Sarekat Islam, dekat pula dengan KH. Misbah (Komunis), dan 


\section{MUHAMMADIYAH DAN POLITIK}

termasuk dekat dengan kalangan Ahmadiyah. 22 Banyak aktivis Muhammadiyah, termasuk KH. Ahmad Dahlan sendiri yang aktif di organisasi lain, baik Sarekat Islam maupun Budi Utomo. ${ }^{23}$ Pada periode selanjutnya, KH. Mas Mansur bahkan terlibat dalam pendirian Partai Islam Indonesia (PII). Pada Tanwir Muhammadiyah tahun 1938, Muhammadiyah memutuskan untuk mengijinkan KH. Mas Mansur -yang saat itu menjabat sebagai Ketua Muhammadiyah-menjadi pimpinan PII.

Bersama NU dan PSII, tahun 1937 Muhammadiyah juga terlibat dalam pendirian Majlisul Islam A'la Indonesia (MIAI). ${ }^{24}$ Ketika lahir Masyumi yang pendiriannya difasilitasi Pemerintah Jepang tahun 1943, Muhammadiyah pun terlibat di dalamnya. Oleh Ricklefs, berdirinya MIAI disebutnya sebagai upaya untuk mengendalikan Islam. ${ }^{25}$ Sementara Benda menyebut bahwa diciptakannya Masyumi yang diberi status hukum langsung pada hari didirikannya, tak ayal lagi merupakan kemenangan politik Jepang terhadap Islam. ${ }^{26}$ Lahirnya Masyumi merupakan salah satu cara Jepang untuk mengendalikan umat Islam.

Selepas Jepang menyerah tanpa syarat kepada Sekutu pada Agustus 1945, maka pada September 1945 berkumpul para tokoh Islam, seperti Agus Salim, Abi Kusno, Mohammad Natsir, Wali Alfatah, Sukiman, dan Gafar Ismail untuk mengadakan musyawarah merencanakan pembentukan partai. Ide ini diperkuat oleh Maklumat Pemerintah Nomor X tanggal 3 Nopember 1945. Tokoh-tokoh Islam menyambut baik anjuran pemeritah ini. Pada tanggal 7 dan 8 Nopember 1945 diselenggarakan Kongres Umat Islam Indonesia di Yogyakarta. Salah satu keputusan kongres tersebut adalah dibentuknya partai politik yang dapat menyalurkan aspirasi politik umat Islam yang sekaligus menjadi satu-satunya partai politik yang mewakili umat Islam di Indonesia. Partai ini disepakati dengan nama Partai Politik Islam Majlis Syura Mulimin Indonesia (Masyumi). ${ }^{27}$ 
Di institusi politik baru ini, Muhammadiyah (bersama NU) menjadi anggota istimewa. Ketelibatan Muhammadiyah ke dalam Masyumi menjadi catatan bahwa inilah sekali-kalinya Muhammadiyah secara struktural memfusi ke dalam partai politik. Sebelum pembubaran Masyumi tahun 1960, tepatnya tahun 1959, Muhammadiyah menanggalkan keanggotaan istimewanya, yang berarti berakhir pula keanggotaan Muhammadiyah di Masyumi.28

Secara politik, Muhammadiyah juga sempat mengalami masa-masa sulit. Pada awal 1960-an, ketika ada upaya dari sebagian warga Muhammadiyah yang hendak menjadikan Muhammadiyah sebagai partai politik, namun upaya tersebut dapat digagalkan oleh mainstream warga Muhammadiyah yang menolak upaya tersebut. Saat transisi politik dari Orde Lama ke Orde Baru, Muhammadiyah juga dihadapkan pada pilihan serupa, antara menjadi partai politik; menghidupkan kembali Masyumi; dan atau bersama ormas Islam lain membentuk partai politik baru. Gamangnya posisi politik Muhammadiyah tergambar dari putusan Khittah Ponorogo 1969 dan Khittah Ujungpandang 1971, yang sangat beraroma politik. Isi Khittah 1969 yang merupakan hasil Tanwir Ponorogo, terutama poin 5-9, isinya sangat beraroma politik:

Poin 5: Muhammadiyah sebagai organisasi memilih dan menempatkan diri sebagai "Gerakan Islam dan Amar Makruf Nahi Munkar dalam bidang masyarakat”. Sedang untuk alat perjuangan dalam bidang politik kenegaraan (politik praktis), Muhammadiyah membentuk satu partai di luar organisasi Muhammadiyah. Poin 6: Muhammadiyah harus menyadari bahwa partai tersebut adalah merupakan obyeknya dan wajib membinanya. Poin 7: Antara Muhammadiyah dan partai tidak ada hubungan organisatoris, tetapi tetap mempunyai hubungan ideologis. Poin 8: Masing-masing berdiri dan berjalan sendiri-sendiri, tetapi dengan saling pengertian dan menuju tujuan yang satu. Poin 9: Pada prinsipnya tidak dibenarkan adanya 


\section{MUHAMMADIYAH DAN POLITIK}

perangkapan jabatan, terutama jabatan pimpinan antara keduanya, demi tertibnya pembagian pekerjaan. ${ }^{29}$

Seakan mengoreksi Khittah Ponorogo, melalui Khittah Ujungpandang, Muhammadiyah mencoba menjaga jarak kembali dengan partai politik meskipun masih memandang positif terhadap Parmusi dan partai lainnya. Khittah Ujungpandang ini diputuskan melalui Muktamar ke-38 tahun 1971. Dalam salah satu poin (3) Khittah Ujungpandang, disebutkan bahwa:

“3. Untuk lebih memantapkan Muhammadiyah sebagai Gerakan Dakwah Islam setelah Pemilu 1971, Muhammadiyah melakukan Amar Makruf Nahi Munkar secara konstruktif dan positif terhadap Partai Muslimin Indonesia (Parmusi) seperti halnya terhadap partai-partai politik dan organisasiorganisasi lainnya." 30

Muktamar Ujungpandang berlangsung beberapa bulan selepas Pemilu 5 Juli 1971. Muhammadiyah mempunyai andil besar dalam pendirian Parmusi. Bahkan dua jabatan strategis Parmusi dijabat oleh dua kader Muhammadiyah. Ketua Umum dijabat Djarnawi Hadikusumo ${ }^{31}$ dan Sekretaris Jenderal dijabat Lukman Harun. ${ }^{32}$ Saat Kongres I Parmusi di Malang tahun 1968, secara demokratis berhasil memilih Mohammad Roem sebagai Ketua Umum. Namun karena Soeharto tidak "merestui", 33 maka kepemimpinan Parmusi dikembalikan kepada Djarnawi Hadikusumo.

Secara mengejutkan, Jaelani Naro, salah satu Ketua Parmusi dari unsur Al-Washliyah, pada 17 Oktober 1970 mengumumkan pengurus Parmusi tandingan dan mengklaim sebagai ketua umum. Terjadi saling pecat memecat. Atas nama disiplin partai, Djarnawi memecat Naro dan gantian Naro memecat Djarnawi. Dalam perjalanannya, Soeharto yang tengah melakukan konsolidasi politik dan penataan sistem kepartaian, ${ }^{34}$ melakukan "kudeta politik" dengan mengesahkan susunan pengurus baru dan 
mengangkat HMS Mintardja sebagai Ketua Umum Parmusi. Sementara Djarnawi dan Naro, tidak masuk dalam susunan pengurus baru. Namun belakangan, Naro justru masuk menjadi salah satu Ketua Parmusi "versi Soeharto". 35

Dengan situasi politik seperti ini, bisa dipahami apabila pada Muktamar Ujungpandang, Muhammadiyah membuat Khittah dengan menyebut Parmusi, meski penyebutannya masih diikuti dengan kata-kata: “...seperti halnya terhadap partai-partai politik dan organisasi-organisasi lainnya." Artinya, Muhammadiyah sudah mencoba memutus keterkaitan dengan partai manapun. Namun karena andil besar dalam proses pendirian Parmusi, Muhammadiyah tidak bisa sertamerta memutus relasinya dengan Parmusi secara ekstrim.

Baru pada Tanwir 1978 di Surabaya, Muhammadiyah membuat Khittah lebih tegas lagi dalam relasinya dengan partai politik. Tanwir ini berlangsung selepas Pemilu 1977. Parmusi sudah memfusi ke dalam wadah baru politik umat Islam bernama Partai Pesatuan Pembangunan (PPP), ${ }^{36}$ sehingga dapat menjadi pembenar bagi Muhammadiyah untuk menjauh dari Parmusi, dan partai lainnya. Berikut butir-butir dari putusan Khittah Surabaya 1978.

1. Muhammadiyah adalah Gerakan Da'wah Islam yang beramal dalam segala bidang kehidupan manusia dan masyarakat, tidak mempunyai hubungan organisatoris dengan dan tidak merupakan afiliasi dari sesuatu partai politik atau organisasi apapun.

2. Setiap anggota Muhammadiyah sesuai dengan hak asasinya dapat tidak memasuki atau memasuki organisasi lain, sepanjang tidak menyimpang dari Anggaran Dasar, Anggaran Rumah Tangga, dan ketentuanketentuan yang berlaku dalam Persyarikatan Muhammadiyah.

Ketika negara mencanangkan asas tunggal Pancasila, Muhammadiyah juga mengalami dilema, yang tergambar dari keputusan hasil Tanwir 1983 


\section{MUHAMMADIYAH DAN POLITIK}

terkait asas tunggal. Sidang Tanwir menyimpulkan tiga poin terkait asas tunggal.

1. Muhammadiyah setuju memasukkan Pancasila dalam Anggaran Dasar Muhammadiyah dengan tidak mengubah asas Islam yang ada sekarang ini.

2. Masalah tersebut adalah masalah nasional yang dihadapi oleh Pimpinan Pusat Muhammadiyah secara nasional. Oleh karena itu, Pimpinan Wilayah, Pimpinan Daerah, dan lain-lain tidak dibenarkan untuk mengeluarkan pendapat ataupun mengambil sikap mengenai "asas tunggal" tersebut.

3. Membahasannya akan dilakukan dalam Muktamar ke-41 yang akan datang. ${ }^{37}$

Pada Muktamar ke-41 di Surakarta, 7-11 Desember 1985, 38 Muhammadiyah menyatakan menerima asas tunggal Pancasila, yang ditandai dengan beberapa keputusan Muktamar, di antaranya mengadakan penyesuaian Anggaran Dasar Muhammadiyah sesuai dengan UU Nomor 8 Tahun 1985 tentang Organisai Kemasyarakatan.

"Persyarikatan ini bernama Muhammadiyah, adalah Gerakan Islam dan Dakwah Amar Ma'ruf Nahi Munkar beraqidah Islam dan bersumber pada al-Qur'an dan Sunnah."39 "Persyarikatan ini berasas Pancasila."40 "Maksud dan tujuan Persyarikatan ialah menegakkan dan menjunjung tinggi agama Islam sehingga terwujud masyarakat utama, adil, dan makmur yang diridhai Allah Subhanahu wata'ala."41

Penerimaan Muhammadiyah atas asas tunggal Pancasila tidak cukup mudah. Penyebabnya, negara melakukan segala cara agar asas tunggal 
Pancasila dapat diterima. Tidak saja di tingkat pusat, tekanan juga dirasakan oleh Muhammadiyah di tingkat daerah. Pimpinan militer di tingkat Kodim “menekan” ormas-ormas Islam di tingkat daerah dengan cara mengundang mereka ke Makodim dan memintanya agar membuat deklarasi penerimaan asas tunggal Pancasila. Selain itu, pemahaman keagamaan model skripturalis juga cukup mendominasi di Muhammadiyah, dan tentunya kurangnya sosialisasi atas RUU Ormas, membuat Muhammadiyah tidak cukup mudah menerima asas tunggal Pancasila. ${ }^{42}$

Seiring tumbangnya rezim Orde Baru, saat Tanwir Semarang Juni 1998, Muhammadiyah membuat rekomendasi politik, yang salah satu butirnya kerap ditafsir sebagai pembenar bagi berdirinya PAN. Rekomendasi ini telah mempercepat proses pembentukan PAN di daerah-daerah. Euphoria politik warga Muhammadiyah benar-benar dilampiaskan ke PAN. Meski diluar estimasi awal, di mana PAN diprediksi akan menjadi partai papan atas, namun perolehan suara PAN pada Pemilu 1999 tidak cukup mengecewakan. Pada Pemilu 1999, PAN memperoleh 7,12\% suara. Sementara Pemilu 2004 sedikit mengalami penurunan dengan hanya meraih 6,44\% suara. Penurunan suara kembali dialami PAN pada Pemilu 2009 dengan perolehan suara sebesar 6,1 persen. Pada Pemilu 2014 PAN mengalami kenaikkan suara menjadi 7,59\%.

Tabel 7

Perolehan Suara dan Kursi PAN

\begin{tabular}{|c|c|c|c|c|c|c|c|}
\hline Pemilu & Suara & $\%$ & $\begin{array}{c}\text { Kur } \\
\text { si }\end{array}$ & $\begin{array}{c}\text { Pemil } \\
\text { u }\end{array}$ & Suara & $\%$ & Kursi \\
\hline 1999 & 7.528 .956 & $\begin{array}{c}7,12 \\
\%\end{array}$ & 34 & 2009 & $\begin{array}{c}6.254 .58 \\
0\end{array}$ & $\begin{array}{c}6.01 \\
\%\end{array}$ & 43 \\
\hline 2004 & 7.303 .324 & $\begin{array}{c}6.44 \\
\%\end{array}$ & 52 & 2014 & $\begin{array}{c}9.481 .62 \\
1\end{array}$ & $\begin{array}{c}7.59 \\
\%\end{array}$ & 49 \\
\hline
\end{tabular}




\section{MUHAMMADIYAH DAN POLITIK}

Seakan sejarah terulang kembali, Tanwir Denpasar 2002, Muhammadiyah kembali membuat keputusan normatif terkait posisi nonafiliatif Muhammadiyah. Perubahan sikap ini persis seperti perubahan sikap dari Khittah Ujungpandang ke Khittah Surabaya. Pada poin 6 keputusan Tanwir Denpasar disebutkan:

"Muhammadiyah tidak berafiliasi dan tidak mempunyai hubungan organisatoris dengan kekuatan-kekuatan politik atau organisasi manapun. Muhammadiyah senantiasa mengembangkan sikap positif dalam memandang perjuangan politik dan menjalankan fungsi kritik sesuai dengan fungsi amar makruf nahi munkar demi tegaknya sistem politik kenegaraan yang demokratis dan berkeadaban."43

Pada Tanwir Mataram 2004, Muhammadiyah juga seakan melakukan pembiaran atas lahirnya salah satu poin Rekomendasi Tanwir, yang kemudian ditafsir sebagai "lampu hijau" bagi bolehnya Angkatan Muda Muhammadiyah (AMM) untuk mendirikan partai politik baru.

"Berkaitan dengan dinamika internal dalam Muhammadiyah pasca Pemilu 2004, Tanwir dapat menangkap dan mencatat munculnya keinginan atau aspirasi warga Muhammadiyah, terutama dari Angkatan Muda muhammadiyah untuk mendirikan partai politik baru. Tanwir berpandangan bahwa gagasan tersebut hendaknya dipertimbangkan secara lebih matang dan tidak terburu-buru, karena pendirian partai politik baru harus didasarkan pada pemikiran mendalam dan bukan karena alasan kekecewaan atau sekedar keinginan untuk memperebutkan kursi kekuasaan politik. Tanwir memberikan kesempatan kepada Angkatan Muda Muhammadiyah untuk menindaklanjuti dan mengkaji gagasan tersebut secara lebih komprehensif dengan selalu memperhatikan 
nilai-nilai dasar Persyarikatan dan tidak menyeret Muhammadiyah dalam politik praktis." 44

Rekomendasi Tanwir ini ditafsir secara "nakal" oleh AMM dengan mendirikan Partai Matahari Bangsa (PMB), yang dibangun penuh idealisme dan berhasil lolos pada Pemilu 2009. Namun modal idealisme yang tidak dibarengi kecukupan modal ekonomi ternyata tidak cukup kuat untuk mempengaruhi realitas politik Indonesia yang begitu pragmatis. PMB pun hanya menjadi partai 0 , (baca nol koma) dengan memperoleh tidak sampai 1 persen suara.

\section{Dilema antara Keep Close dan Keep Distance}

Itulah gambaran singkat relasi Muhammadiyah dan politik, yang pasang surut dan pola relasinya tidak statis, tapi sangat dinamis. Tergambar adanya dilema antara "menjaga jarak" (keep close) dengan "menjaga kedekatan" (keep distance). Satu sisi ada keinginan untuk "menjaga jarak" dengan semua kekuatan politik, namun di sisi lain terkadang muncul keinginan untuk “menjaga kedekatan" yang sama dengan semua kekuatan politik. Pasang surut relasi Muhammadiyah dengan partai politik, termasuk dengan PAN, menggambarkan adanya relasi yang dilematis.

Pola relasi politik ini praktis tidak mengalami perubahan berarti. Pasca Tanwir Mataram hingga saat ini, Muhammadiyah masih kerap mengeluarkan "kebijakan politik" yang terkadang mengundang polemik di lingkup internal Muhammadiyah. Misalnya SK PP Muhammadiyah Nomor 149 tentang Kebijakan Muhammadiyah terkait konsolidasi organisasi dan Amal Usaha. SK ini memberi batasan jelas antara Muhammadiyah sebagai gerakan sosial keagamaan dan PKS/ Tarbiyah yang merupakan gerakan politik. Berikutnya SK PP Muhammadiyah Nomor 101 tentang Ketentuan Jabatan di Lingkungan Persyarikatan yang tidak dapat dirangkap dengan jabatan lain. SK ini di 
antaranya secara tegas mengatur soal rangkap jabatan di Muhammadiyah dengan jabatan di partai politik.

Secara mormatif organisatoris, keluarnya dua SK ini sebenarnya menggambarkan sikap dan posisi politik Muhammadiyah yang dilematis, untuk tidak menyebut inkonsisten. Satu sisi Muhammadiyah mencoba menegaskan posisi politiknya dalam kaitan relasi partai politik. Namun di sisi lain, terkadang Muhammadiyah juga mencoba "mendekat" dengan kekuasaan politik atau partai politik. Beberapa kali Muhammadiyah secara kelembagaan misalnya mengadakan temu silaturrahim dengan para anggota DPR RI dan DPD RI yang dinilai sebagai kader atau setidaknya mempunyai irisan ideologis maupun biologis dengan Muhammadiyah.

Bila menilik pada dua figur ketua (umum) Muhammadiyah terakhir, yaitu Ahmad Syafii Maarif dan Din Syamsuddin, merupakan dua sosok yang juga merepresentasikan dua langgam mainstream di Muhammadiyah dalam relasinya dengan politik. Syafii Maarif (1998-2005) menggambarkan langgam politik keep close. Sementara Din Syamsuddin (2005-2015) lebih menggambarkan langgam yang keep distance.

Dua langgam ini tampak dipengaruhi oleh pribadi Syafii Maarif maupun Din Syamsuddin. Bila Syafii Maarif mencerminkan "kekakuan" Muhammadiyah dalam relasinya dengan partai politik, ${ }^{45}$ sebaliknya Din Syamsuddin menjadi gambaran "kelunakan" dalam relasinya dengan partai politik, ${ }^{46}$ sehingga wajar ketika langgamnya lebih "lunak" dan realistis. ${ }^{47}$ Meskipun begitu, hal yang menarik, dua SK tersebut di atas justru keluar di era kepemimpinan Din Syamsuddin.

Konsekuensi dari langgam keep distance, Muhammadiyah dituntut untuk benar-benar istiqamah menjaga kedekatan yang sama dengan semua partai politik, termasuk kandidat-kandidat calon presiden (capres). Muhammadiyah tidak boleh menunjukan keberpihakan kepada kandidat tertentu, ketika keberpihakan tersebut semata dilandasi oleh kepentingan 
politik yang bersifat pragmatis, misalnya sekadar berharap ada kader Muhammadiyah yang nantinya akan dipinang menjadi pasangan capres tertentu. Sikap pragmatis itu wilayahnya partai politik, dan Muhammadiyah itu bukan partai politik, sehingga tidak tepat bila Muhammadiyah terperangkap pada politik dukung mendukung yang bersifat pragmatis. Kalau pun Muhammadiyah harus "berpihak", maka keberpihakannya tetap dalam koridor Khittah dan harus tetap berangkat dari apa "yang seharusnya” (das sollen) dan bukan apa "yang senyatanya" (das sein). Keberpihakan Muhammadiyah harus didasarkan pada nilai-nilai normatif dan idealitas politik. Kalau pun misalnya Muhammadiyah akan mendukung kandidat capres tertentu, cara yang ditempuhnya harus tetap elok.

Begitu juga kalau misalnya ada kader Muhammadiyah yang layak dan menjadi "rebutan" beberapa capres, pilihan untuk mendampingi capres tertentu pun harus tetap didasarkan pada nilai-nilai idealitas. Capres yang akan dipilih bukan hanya karena pertimbangan popularitasnya, tapi harus mendasarkan pada visinya, terutama visi yang terkait dengan beberapa persoalan bangsa yang krusial dan akut, seperti visi terkait pemberantasan korupsi, pembangunan sistem politik, ekonomi, dan hukum yang bermartabat, dan visi terkait kemandirian bangsa.

Karena acuannya adalah Khittah dan nilai-nilai idealitas politik, maka menjadi kurang elok ketika misalnya pada saat menjelang Pilpres 2014 lalu Muhammadiyah menerima calon presiden tertentu dan memberikan kesempatan yang bersangkutan untuk menjadi imam salat (meskipun hanya imam salat dhuhur, yang bacaan imamnya sirri).

Merujuk pada kebiasaan Rasul Muhammad saw. di saat sakitnya, yang kerap memberikan kesempatan kepada Abu Bakar untuk menggantikannya menjadi imam salat, yang kemudian ditafsir oleh umat Islam saat itu sebagai "sinyal dukungan", bahwa estafet kepemimpinan umat Islam pasca Rasul akan jatuh ke tangan Abu Bakar -dan dalam perjalanan sejarahnya memang 


\section{MUHAMMADIYAH DAN POLITIK}

terbukti, pemberian kesempatan untuk menjadi imam salat pada calon presiden tertentu, tentu akan ditasir sebagai bentuk "sinyal dukungan" yang bersifat simbolik dari Muhammadiyah kepada calon presiden bersangkutan.

Padahal bila menengok fiqh salat terkait dengan persyaratan ideal untuk menjadi imam salat, tidaklah gampang: harus orang yang paling baik bacaannya (aqra'uhun); orang yang paling wara' atau mampu menjaga diri dari hal yang bersifat syubhat sekalipun; dan orang yang paling tua usianya. Bagi Abu Bakar, untuk memenuhi persyaratan tersebut tentu bukanlah sesuatu yang sulit.

Kasus "imam salat" ini sedikitnya telah menciderai posisi politik Muhammadiyah. Secara simbolik, kasus "imam salat" ini juga bisa ditafsir sebagai bentuk "kegenitan" atau keinginan dari Muhammadiyah untuk mengambil peran-peran politik yang bersifat praktis dan pragmatis. Dan kalau Muhammadiyah sampai jatuh pada kubangan pragmatisme politik, lantas apa bedanya dengan partai politik. Tentu ini merupakan kemunduran, untuk tidak mengatakan kemerosotan Muhammadiyah dalam berpolitik.

Paparan di atas adalah realitas politik yang kerap memaksa Muhammadiyah untuk mengambil sikap politik. Sebagai organisasi yang hidup dalam sebuah sistem politik, tentu tak mungkin bagi Muhammadiyah untuk berdiam diri. Namun sikap Muhammadiyah ini terkadang dikritisi dan dibaca sebagai inkonsistensi Muhammadiyah sebagai ormas keagamaan. Muhammadiyah dinilai kerap di(ter)goda untuk masuk wilayah politik yang tidak seharusnya, yaitu politik yang dominan berorientasi pada kekuasaan dan politik dukung mendukung pada kandidat tertentu, terlebih saat pemilihan presiden.

Kenapa Muhammadiyah kerap bersikap yang cenderung ambigu dalam relasinya dengan politik? Ada dilema yang kuat antara keep close dengan keep distance. Setidaknya ada dua hal yang mendasarinya dan sekaligus menjadi jawaban. Pertama, pandangan mainstream di lingkup Muhammadiyah yang 
menyebut bahwa Islam al-din wa al-dawlah, Islam adalah agama dan negara, Islam dan negara adalah dua entitas yang tidak bisa dipisahkan. Islam tidak berwatak sekuralistik yang memisahkan agama dan negara, tapi berwatak integralistik. Pandangan ini diperkuat oleh realitas historis bahwa Muhammadiyah yang lahir jauh sebelum kemerdekaan, mempunyai andil besar dalam kemerdekaan Indonesia. Sebagai bentuk tanggung jawab, terlebih dalam konteks pergantian kepemimpinan nasional, Muhammadiyah merasa perlu ikut cawe-cawe. Kedua, bangsa ini, terlebih di lingkup pimpinan nasional yang terpilih dalam proses politik, utamanya sejak pasca Orde Baru, kerap tidak proporsional dalam memposisikan Muhammadiyah sebagai ormas keagamaan. Perlakuannya terkadang persis seperti kepada partai politik, yang untuk memperoleh kuasa politik -sebagaimana lazimnyadituntut untuk terlibat dalam politik dukung mendukung. Sikap yang tidak proporsional ini terkadang membawa Muhammadiyah pada posisi politik yang terkesan partisan, posisi yang -dalam konteks demokrasi- hanya pantas disandang oleh partai politik.

\section{Penutup}

Dibutuhkan adanya kesadaran dalam memposisikan Muhammadiyah secara proporsional. Muhammadiyah lahir jauh sebelum Indonesia merdeka. Sumbangsihnya terhadap bangsa dan negara ini tak terhingga, utamanya dalam bidang dakwah amar makruf nahi munkar, sosial, pendidikan, dan kesehatan. Karenanya, semestinya posisikan "orang tua” bangsa ini dalam posisi yang selayaknya dalam kaitan relasinya dengan politik. Jangan memancing “orang tua” ini terlibat dalam politik dukung mendukung, apalagi hanya sekadar mendapatkan jabatan-jabatan politik. Memancing organisasi keagamaan seperti Muhammadiyah untuk terjun dan terlibat dalam ranah politik, apalagi politik dalam pengertian "murahan" sekadar berebut kekuasaan, tentu sikap yang jauh dari elok dan buta akan sejarah (ahistoris). 


\section{MUHAMMADIYAH DAN POLITIK}

Kalau elit politik negeri ini mampu memposisikan Muhammadiyah secara proporsional, Muhammadiyah juga akan memposisikan secara proporsional pula, semata sebatas sebagai ormas keagamaan yang selalu berorientasi pada politik kebangsaan dan menjauhkan dari dari orientasi politik partisan. Memposisikan Muhammadiyah secara proporsional setidaknya harus dilihat dalam dua hal. Pertama, yakinkan Muhammadiyah bahwa partai-partai politik maupun politisi yang ada di lembaga eksekutif maupun legislatif mampu menghasilkan produk politik berupa kebijakankebijakan politik yang sepenuhnya diperuntukan untuk kemaslahatan masyarakat. Faktanya, yang terjadi justru lebih sering produk kebijakan politik berlawanan secara diametral dengan kepentingan dan kemaslahatan masyarakat.

Kedua, dalam konteks kompetisi perebutan jabatan-jabatan politik, partai-partai politik juga harus mampu meyakinkan Muhammadiyah dengan menawarkan kandidat-kandidat politik yang senafas dengan misi dakwah Muhammadiyah, dan kepentingan masyarakat banyak. Jangan lukai perasaan Muhammadiyah khususnya dan umat Islam pada umumnya dengan misalnya memunculkan kandidat-kandidat politik kelas comberan yang tidak saja tak berguna bagi bangsa ini, tapi juga menjadi problem maker bagi bangsa ini. Pilkada DKI Jakarta 2017, di mana mayoritas partai politik menawarkan kandidat bernama Basuki Tjahaya Purnama (Ahok) adalah cermin kebijakan politik partai yang tidak sensitif dan gagal dalam memahami serta menyelami perasaan warga DKI Jakarta.

Mencalonkan Ahok adalah cermin kebijakan parta-partai yang tidak memahami demokrasi dengan baik. Lazimnya, dalam sistem politik demokrasi, suara mayoritas itu menjadi pertimbangan utama dalam membuat kebijakan politik. Dalam kasus Pilkada DKI Jakarta, prinsip demokrasi diabaikan begitu saja. Pencalonan Ahok juga cermin mendasar bahwa partai-partai pengusungnya gagal paham tentang Indonesia dan 


\section{MA'MUN MUROD AL-BARBASY}

Pancasila. Ahok adalah pencerminan nyata dari sosok yang tidak paham Indonesia dan Pancasila. Tentu aneh ketika sosok yang gagal paham tentang Indonesia dan Pancasila justru diusung untuk menduduki jabatan publik oleh partai-partai yang selama ini lebih sering berteriak tentang dan merasa diri paling NKRI, Pancasila, dan pro wong cilik. Akhirnya, semoga Pilkada DKI Jakarta dapat menjadi pembelajaran bagi semua partai politik dalam memuat kebijakan-kebijakan politik di masa mendatang, terlebih dalam mengusung kandidat-kandidat politik yang akan menduduki jabatan di ranah publik. Semoga.

\section{Catatan:}

1 PP. Muhammadiyah, Keyakinan dan Cita-cita Hidup Muhammadiyah, Yogyakarta: PP. Muhammadiyah, 1989, hal. 11

${ }^{2}$ Secara de facto, Khilafah Usmaniyah sebenarnya telah dibekukan sejak tahun 1922. Lewat pembekuan ini, nyaris kekuasaan yang dimiliki Khalifah Abdul Madjid terkikis habis. Baru pada tahun 1924, Mustofa Kemal At-Taturk secara resmi berhasil menghapuskan Khilafah Utsmaniyah

${ }^{3}$ Hussein sangat berharap hadirnya kembali khilafah yang berpusat di Makkah. Untuk merealisasikan keinginannya, Hussein membentuk Dewan Penasehat Khalifah yang dua anggotanya di antaranya berasal dari Asia Tenggara yang bermukim di Makkah. Hussein juga bermaksud mengadakan Kongres Haji (Muktamar Al-Hajj) di Makkah Juli 1924, dengan harapan mendapat dukungan untuk klaimnya sebagai khalifah. Namun muktamar tersebut gagal mencapai kata sepakat untuk memberikan dukungan pada Hussein. Baca Martin van Bruinessen, 1994, NU, Tradisi, Relasi-relasi Kuasa, Pencarian Wacana Baru, Yogyakarta: LKiS, 1994, hal. 28

"Ibnu Saud menilai bahwa Hussein hanya mementingkan diri sendiri, tak mementingkan persatuan dan kemerdekaan dunia Arab. Hussein juga dianggap sebagai penghalang Gerakan Wahabi (tepatnya Muwahidin, Gerakan Pemurnian Tauhid) yang dianut Ibnu Saud. Wahabi merupakan gerakan keagamaan yang didirikan oleh Muhammad bin Abdul Wahab (1787) di Najed pada penghujung abad ke-19. Gerakan ini ingin mengembalikan ajaran Islam pada rel yang sebenarnya, yaitu kembali kepada al-Qur'an dan Hadits, membuka lebar-lebar pintu ijtihad dan membunuh taqlid yang membabi buta, mengikis habis bid'ah, khurafat, dan tahayul. Hussein dianggap telah membiarkan ajaran Islam sarat dengan bid'ah dan khurafat. Terjadi pertempuran antara tentara ibnu Saud melawan tentara Hussein. Hussein mengalami kekalahan tahun 1924. Hussein meninggalkan Hijaz dan lari ke Kepulauan Cyprus untuk mengasingkan diri. Syarief Ali, putera Hussein mencoba 


\section{MUHAMMADIYAH DAN POLITIK}

menggantikan kedudukan ayahnya. Namun Ali pun menyerah tahun 1926. Dengan menyerahnya Ali, tercapai keinginan Ibnu Saud untuk mempersatukan Jazirah Arab di bawah satu kekuasaan. Mulailah Ibnu Saud melakukan gebrakan dengan membersihkan kebiasaan praktek-praktek keagamaan yang tak sesuai ajaran Islam dan merombak praktek-praktek keagamaan, seperti membongkar kultus bagi orangorang suci, bangunan-bangunan makam, dan apa saja yang dianggap keramat walau itu makam keluarga Nabi dan Sahabat Khulafa-u al-Rasyiddin: Abu Bakar, Umar bin Khattab, Utsman bin Affan, dan Ali bin Abi Thalib yang ada di sekitar Kabah; membuka lebar-lebar pintu ijtihad dan membunuh taqlid yang membabi buta; dan mencela habis-habisan mereka yang masih mau tunduk pada madzhab. Lihat Munawir Sjadzali, Islam dan Tata Negara: Ajaran, Sejarah dan Pemikiran, Jakarta: UI Press, 1986, hal. 111-137.

${ }^{5}$ Saat terjadi pertempuran antara Ibnu Saud dan Hussein, diam-diam para ulama Al-Azhar yang mendapat dukungan dari Raja Fuad sedang melakukan persiapan untuk mengadakan Kongres Khilafah. Kongres ini sedianya diadakan pada Maret 1925, tapi karena beberapa kendala diundur sampai Mei 1926. Mendengar Fuad sedang menyiapkan kongres, Ibnu Saud mencoba membuat kongres tandingan di Makkah. Ibnu Saud berpandangan, kalau Kongres Mesir terlaksana dan Fuad terpilih sebagai khalifah, akan menjadi ancaman atas posisi yang baru dimenangkannya. Untuk menghindari hal ini, pura-pura agenda pembicaraan kongres difokuskan pada masalah Haji. Meski sebenarnya kongres tersebut tidak lain bertujuan untuk memperoleh legitimasi bagi kekuasaan Ibnu Saud atas Hijaz. Kongres Mesir memutuskan bahwa masalah khilafah bagi umat Islam masih cukup penting, guna mengagungkan kalimat Allah dan mempertahankan kebesaran Islam. Namun diakui bahwa khilafah dalam arti yang sebenarnya hanya terdapat pada jaman klasik ketika seluruh daerah dapat diikat dalam satu perintah dan satu organisasi. Akhirnya kongres berpendapat, hampir mustahil menegakkan tahta khalifah kembali. Meski begitu kongres tetap memberikan saran dan gagasan untuk pembentukan khilafah. Bahasan tentang hal ini, lihat juga dalam Aqib Suminto, Politik Islam Hindia Belanda, Jakarta: LP3ES, 1985, hal. 165-167.

${ }^{6}$ Ibid.

${ }^{7}$ Tashwirul Afkar berdiri 1914 oleh KH. Abdul Wahab Hasbullah (pada perkembangannya menjadi salah satu pendiri NU dan pernah menjadi Rais Am Syuriah PBNU) dan KH. Mas Mansur (pada perkembangannya menjadi tokoh penting di Muhammadiyah dan pernah menjadi Ketua PB Muhammadiyah). Tashwirul Afkar dalam perkembangannya kemudian menjadi embrio lahirnya NU. Bahasan tentang hal ini, lihat Slamet Effendy Yusuf, et. al., Dinamika Kaum Santri: Menelusuri Jejak dan Pergolakan Internal NU, Jakarta: Rajawali, 1983, hal. 7-8.

8Pada Kongres I dan II dimaksudkan untuk menggalang persatuan dan kesatuan umat Islam dalam upaya menghadapi Pemerintah Kolonial Belanda, tapi rupanya peserta kongres masih terbawa oleh pembicaraan yang terkait dngan persoalan khilafiyah dan furu'iyah lainnya, termasuk di dalamnya membahas Tafsir 
al-Manar, kongres sudah mengalami kemajuan. Dari Kongres ini dihasilkan, pertama, membuat Central Comitte Chilafah (CCC) -yang sebelumnya sudah dirumuskan pada pertemuan di Surabaya, 4 Oktober 1924 dengan ketua Wondo Sudirdjo -berubah nama menjadi Wondoamiseno- dari SI dan wakilnya KH. Abdul Wahab Hasbullah (Tashwirul Afkar). Kedua, memutuskan mengirim delegasi ke Kongres Mesir yang terdiri dari Suryopranoto (SI), H. Fakhruddin (Muhammadiyah) dan KH. Abdul Wahab Hasbullah (Tashwirul Afkar). Sebagaimana disebutkan di atas, karena Kongres Mesir mengalami pengunduran sampai tanggal 13-19 Mei 1926. Akhirnya delegasi tersebut pun dibatalkan. Lihat Ma'mun Murod Al-Barbasy, Ambiguitas Politik Kaum Santri, Jakarta: Grafindo, 2012), hal. 23-25.

${ }^{9}$ Lihat Junus Salam, KH. A. Dahlan, Amal, dan Perjuangannya, Jakarta: Depot Pengajaran Muhammadiyah, 1968, hal. 33.

10 Baca lebih jauh dalam Musthafa Kamal Pasha, Adabi Darban, Muhammadiyah sebagai Gerakan Islam dalam Perspektif Historis dan Ideologis, Yogyakarta: LPPI UMY, 2002.

11Deliar Noer, Gerakan Moderen Islam di Indonesia 1900-1942, Jakarta: LP3ES, 1994.

${ }^{12}$ Alfian, Politik Kaum Modernis: Perlawanan Muhammadiyah terhadap Kolonialisme Belanda, Jakarta: Al-Wasat, 2010.

${ }^{13}$ Alwi Shihab, Membendung Arus: Respon Gerakan Muhammadiyah terhadap Penetrasi Misi Kristen di Indonesia, Bandung: Mizan, 1998.

${ }^{14}$ Achmad Jainuri, Ideologi Kaum Reformis: Melacak Pandangan Keagamaan Muhammadiyah Periode Awal, Surabaya: LPAM, 2002, hal. 78.

15 M. Yusron Asrofie, Kyai Haji Ahmad Dahlan: Pemikiran dan Kepemimpinannya, Yogyakarta: Yogyakarta Press, 1983, hal. 37-38.

16Bahasan tentang hal ini, baca di antaranya dalam Bahtiar Effendy, Islam dan Negara: Transformasi Pemikiran dan Praktik Politik Islam di Indonesia, Jakarta: Paramadina, 2009; Deliar Noer, Gerakan Moderen Islam di Indonesia 1900-1942, Jakarta: LP3ES, 1988.

17"Islam ibadah" dan "Islam politik" meminjam istilah yang ditawarkan Kuntowijoyo dalam, Identitas Politik Umat Islam, (Bandung: Mizan-Majalah ummat, 1997), hal. 197-201.

${ }^{18 K i a i}$ Dahlan dan Kiai Hasyim sohib seperguruan. Ditilik usianya, Kiai Dahlan lebih tua dari usia Kiai Hasyim. Selain itu, keduanya tercatat pernah nyantri di Pesantren Soleh Darat Semarang. Keduanya juga pernah nyantri di Pesantren Langitan Tuban Jawa Timur, sebelum akhirnya keduanya menimba ilmu di Makkah.

${ }^{19}$ Lebih jauh bahasan tentang ordonansi guru, dan juga ordonansi lainnya yang dibuat Pemerintah Kolonial Belanda, Baca Alfian, Politik Kaum Modernis...Op. Cit., hal. 198-297.

${ }^{20}$ Alfian, Politik Kaum...Op. Cit., hal. 186-188.

21Baca Syaifullah, Gerak Politik Muhammadiyah dalam Masyumi, Jakarta: Grafiti, 1997. 


\section{MUHAMMADIYAH DAN POLITIK}

22Kedekatannya dengan Ahmadiyah bukan karena KH. Ahmad Dahlan tak paham soal Ahmadiyah, tapi justru karena KH. Ahmad Dahlan sangat paham dengan Ahmadiyah, bahwa persoalan fundamental Ahmadiyah itu terkait "pengakuan" adanya Nabi selepas Muhammad saw. Ini tentu dari sisi aqidah sangat rawan. Meski begitu, tidak menghalanginya untuk dekat dengan Ahmadiyah. Dalam pandangan KH. Ahmad Dahlan, jangankan dengan kalangan yang masih "berbau" Islam, dengan kalangan non-Islam pun tak boleh menghalanginya untuk saling dekat dan menjalin persahabatan. Kedekatannya dengan Ahmadiyah pun bisa dicari pembenarannya dalam al-Qur'an, yang mengajarkannya untuk menjalin persahabatan dengan siapapun tanpa ada sekat ideologi, agama, warna kulit, bangsa, dan sebagainya (QS. al-Hujurat, 49: 13.

${ }^{23}$ H.M. Sjoedja', Muhammadiyah dan Pendirinya, Yogyakarta: Majlis Pustaka PP. Muhammadiyah, 1989, hal. 27-28.

${ }^{24}$ MIAI didirikan oleh empat tokoh pergerakan Islam, yaitu KH. Wahab Hasbullah (NU), KH. Mohammad Dahlan (NU -bukan pendiri Muhammadiyah, KH. Ahmad Dahlan yang wafat tahun 1923), KH. Mas Mansur (Muhammadiyah -dulunya bersama KH. Wahab Hasbullah mendirikan Tashwirul Afkar, namun karena perbedaan pandangan akhirnya menyatakan mengundurkan diri dari Tashwirul Afkar), dan W. Wondoamiseno (PSII). Beberapa organisasi Islam yang menjadi anggota MIAI adalah PSII, Muhammadiyah, Al-Irsyad, Persatuan Ulama Majalengka, Hidayatul Islamiyah Banyuwangi, dan Khairiyah Surabaya. NU baru masuk secara resmi tahun 1939. Pada Kongres I, 26 Februari-1 Maret 1939 di Surabaya, NU sudah mengirimkan delegasinya, yaitu KH. Abdullah Ubaid. Adapun KH. Wahab Hasbullah dan KH. Mohammad Dahlan yang aktif di MIAI sebelum 1939 bukan mewakili NU, tetapi selaku pendiri dan penasehat MIAI. MIAI berusaha menyatukan semua kekuatan umat Islam. Selama berdirinya, MIAI pernah mengadakan kongres sebanyak tiga kali, tahun 1938, 1939 dan 1941. Topik yang dibicarakan dalam setiap kongres selain menyangkut masalah politik, juga masalah agama. Hanya saja dalam setiap pembahasan masalah agama, yang di bahas selalu permasalahan yang bersifat ikhtilaf dan furuiyah, sehingga terkadang yang timbul adalah perdebatanperdebatan yang tak penting, utamanya bagi kemajuan umat Islam. Baca di antaranya dalam Deliar Noer, Gerakan Moderen...Op. Cit., hal. 262-267. A. Syafii Maarif, Islam dan Masalah Kenegaraan: Studi tentang Percaturan dalam Konstituante, Jakarta: LP3ES, 1995, hal. 17.

25M. C. Ricklefs, Sejarah Indonesia Modern, Yogyakarta: Universitas Gajah Mada, 1995, hal. 304.

${ }^{26}$ Harry Jesus Benda, Bulan Sabit dan Matahari Terbit: Islam Indonesia pada Masa Pendudukan Jepang, Jakarta: Pustaka Jaya, 1980, hal. 185.

${ }^{27}$ Masyumi yang didirikan pasca kemerdekaan ini tidak sama dengan Masyumi yang didirikan oleh Pemerintah Jepang. Masyumi yang lahir di era penjajahan Jepang berdirinya karena inisiatif Jepang dan sebagai strategi untuk mengendalikan umat Islam. Tapi Masyumi yang didirikan 1945 itu lahir dan dibuat sendiri oleh umat Islam tanpa campur tangan pihak luar. Adapun pemakaian nama 
Masyumi hanya semata-mata untuk mempermudah dan juga merupakan hasil Musyawarah bulan Nopember 1945. Lihat A. Syafii Maarif, Islam...Op. Cit., hal. 110.

28Syaifullah, Gerak Politik... Op. Cit., hal. 214-221.

29 Pimpinan Pusat Muhammadiyah, "Keputusan Sidang Tanwir Muhammadiyah, tanggal 25-28 Desember 1969 di Ponorogo tentang Chittah Perdjoangan Muhammadijah", Dokumen, Laporan dan Keputusan Sidang Tanwir, Yogyakarta, 1969.

30Pimpinan Pusat Muhammadiyah, "Keputusan Mukatamar Muhammadiyah ke-38, tanggal 21-26 September 1971 di Ujungpandang, Dokumen, Yogyakarta, 1971.

31Djarnawi Hadikusumo adalah tokoh Muhammadiyah dan putra dari Ki Bagus Hadikusumo yang saat itu menjadi Ketua PB Muhammadiyah, salah satu perumus UUD 1945, dan pengusul perubahan Sila Pertama Pancasila dari "Ketuhanan dengan Menjalankan Syariat Islam bagi Pemeluk-pemeluknya" menjadi hanya "Ketuhanan Yang Maha Esa".

${ }^{32}$ Lukman Harun adalah mantan Ketua Umum Pemuda Muhammadiyah.

${ }^{33}$ Ketidaksetujuan Soeharto terhadap Mohammad Roem lebih disebabkan karena Roem adalah mantan Masyumi. Sementara seperti diketahui, Masyumi dipandang mempunyai catatan politik yang kelam atas keterlibatan beberapa tokohnya dalam Peristiwa PRRI/Permesta di Sumatera Barat. Masyumi juga termasuk yang menentang beberapa kebijakan politik Soekarno, seperti Dekrit Presiden 5 Juli 1959, Demokrasi Terpimpin, dan Nasakom. Sehingga, meskipun tokoh-tokoh Islam modernis yang sebelumnya banyak aktif di Masyumi mempunyai andil besar dalam membantu naiknya Soeharto ke tampuk kekuasaan, berangkat dari pengalaman Soekarno, maka Soeharto tetap mengambil posisi hati-hati terhadap eks Masyumi. Wujud kehati-hatian Soeharto terlihat dalam menyikapi Parmusi. Soeharto melakukan intervensi yang terlalu jauh dengan mengkudeta Roem. Soeharto juga tidak mau merehabilitasi Masyumi.

34Tentang hal ini, baca Ali Moertopo, Strategi Politik Nasional, Jakarta: CSIS, 1974.

${ }^{35}$ Kalau mengikuti sepak terjang politik Naro, munculnya nama Naro dalam konflik di tubuh Parmusi sangat kuat itu bagian dari rekayasa Soeharto untuk menghancurkan kekuatan politik Islam. Naro -atas restu Ali Moertopo- pernah melakukan kudeta atas Mintardja di PPP. Naro juga mempunyai andil besar terhadap kisruh di tubuh PPP jelang Pemilu 1982 terkait nomor urut calon legislatif. Konflik ini kemudian merembet ke tubuh NU dengan munculnya Kubu Cipete dan Kubu Situbondo, yang pada perkembangannya, telah "memaksa" NU untuk menerima Pancasila sebagai asas tunggal Pancasila. Banyak sumber referensi mengupas hal ini. Untuk menyebut beberapa, yaitu Martin van Bruinessen, $N U$, Tradisi...Op. Cit., hal. 90-114; Einar Martahan Sitompul, NU dan Pancasila, Jakarta: Sinar Harapan, 1989, hal. 149-158; M. Ali Haidar, Nahdatul Ulama dan Islam di Indonesia: Pendekatan Fikih dalam Politik, Jakarta: Gramedia, 1994, hal. 198-210; 


\section{MUHAMMADIYAH DAN POLITIK}

dan Rusli M. Karim, Perjalanan Partai Politik di Indonesia, Jakarta: Rajawali Pers, 1983.

36Fusi partai Islam ke dalam PPP terjadi tanggal 5 Januari 1973. Ada empat partai yang melakukan fusi, yaitu NU, Parmusi, PSII, dan Perti.

${ }^{37}$ Lukman Harun, Muhammadiyah dan Asas Pancasila, Jakarta: Pustaka Panjimas, 1986, hal. 37.

${ }^{38}$ Muktamar Muhammadiyah biasanya dilaksanakan pada setiap bulan Juli. Karena menyikapi pembahasan asas tunggal Pancasila yang begitu alot, maka Muhammadiyah memilih untuk memundurkan pelaksanaan Muktamar menjadi di bulan Desember.

${ }^{39}$ Bab I Pasal 1 ayat 1 Anggaran Dasar Muhammadiyah hasil Muktamar Muhammadiyah ke-41 di Surakarta tahun 1985. Lihat dalam M. Shaleh Harun, Abdul Munir Mulkhan, Latar Belakang Ummat Islam Menerima Pancasila sebagai Asas tunggal: Sebuah Kajian Informatif Pandangan NU dan Muhammadiyah, Yogyakarta: Aquarius, $1406 \mathrm{H}$, hal. 224.

${ }^{40}$ Bab II Pasal 2 (Asas) Anggaran Dasar Muhammadiyah. Lihat Ibid., hal. 225.

41Bab II Pasal 3 (Maksud dan Tujuan) Anggaran Dasar Muhammadiyah. Lihat Ibid., hal. 225.

${ }^{42}$ Baca Deliar Noer, Islam, Pancasila dan Asas Tunggal, Jakarta, Yayasan Perhidmatan, 1984. Juga Lukman Harun, Muhammadiyah...Op. Cit.

${ }^{43}$ Hamdan Hambali, Ideologi dan Strategi Muhammadiyah, Yogyakarta: Suara Muhammadiyah, 2006, hal. 152-156.

${ }^{44}$ Lihat Ma'mun Murod Al-Barbasy, Sejarah Berdirinya Partai Matahari Bangsa, Jakarta: PP PMB-Al-Wasat, 2008, hal. 16.

${ }^{45}$ Buya Syafii adalah sosok yang tidak pernah berkecimpung si partai politik, sehingga wajar bila langgam yang ditampilkan terkesan lebih "kaku" dalam menjalin relasi dengan partai politik.

${ }^{46}$ Sebelum menjadi Ketua Umum Muhammadiyah, Bang Din sempat aktif di Golkar dengan menjabat sebagai Ketua Litbang DPP Golkar.

${ }^{47}$ Ma'mun Murod Al-Barbasy, "Muhammadiyah dan Pilpres 2014", dalam Koran Sindo, tanggal 29 Maret 2014. 


\section{DAFTAR PUSTAKA}

Al-Barbasy, Ma'mun Murod, Sejarah Berdirinya Partai Matahari Bangsa, Jakarta: PP PMB-Al-Wasat, 2008.

-------, Ambiguitas Politik Kaum Santri, Jakarta: Grafindo, 2012.

-------, "Muhammadiyah dan Pilpres 2014", dalam Koran Sindo, tanggal 29 Maret 2014.

Alfian, Politik Kaum Modernis: Perlawanan Muhammadiyah terhadap Kolonialisme Belanda, Jakarta: Al-Wasat, 2010.

Asrofie, M. Yusron, Kyai Haji Ahmad Dahlan: Pemikiran dan Kepemimpinannya, Yogyakarta: Yogyakarta Press, 1983.

Benda, Harry Jesus, Bulan Sabit dan Matahari Terbit: Islam Indonesia pada Masa Pendudukan Jepang, Jakarta: Pustaka Jaya, 1980.

Bahtiar Effendy, Islam dan Negara: Transformasi Pemikiran dan Praktik Politik Islam di Indonesia, Jakarta: Paramadina, 2009.

Haidar, M. Ali, Nahdatul Ulama dan Islam di Indonesia: Pendekatan Fikih dalam Politik, Jakarta: Gramedia, 1994.

Hambali, Hamdan, Ideologi dan Strategi Muhammadiyah, Yogyakarta: Suara Muhammadiyah, 2006.

Harun, Lukman, Muhammadiyah dan Asas Pancasila, Jakarta: Pustaka Panjimas, 1986.

Harun, M. Shaleh, Abdul Munir Mulkhan, Latar Belakang Ummat Islam Menerima Pancasila sebagai Asas tunggal: Sebuah Kajian Informatif Pandangan NU dan Muhammadiyah, Yogyakarta: Aquarius, $1406 \mathrm{H}$.

Jainuri, Achmad, Ideologi Kaum Reformis: Melacak Pandangan Keagamaan Muhammadiyah Periode Awal, Surabaya: LPAM, 2002.

Karim, Rusli M., Perjalanan Partai Politik di Indonesia, Jakarta: Rajawali Pers, 1983.

Maarif, A. Syafii, Islam dan Masalah Kenegaraan: Studi tentang Percaturan dalam Konstituante, Jakarta: LP3ES, 1995.

Martin van Bruinessen, 1994, NU, Tradisi, Relasi-relasi Kuasa, Pencarian Wacana Baru, Yogyakarta: LKiS, 1994.

Moertopo, Ali, Strategi Politik Nasional, Jakarta: CSIS, 1974.

Munawir Sjadzali, Islam dan Tata Negara: Ajaran, Sejarah dan Pemikiran, Jakarta: Universitas Indonesia Press, 1986.

Noer, Deliar, Gerakan Moderen Islam di Indonesia 1900-1942, Jakarta: LP3ES, 1994.

-------, Deliar, Islam, Pancasila dan Asas Tunggal, Jakarta, Yayasan Perhidmatan, 1984.

Pasha, Musthafa Kamal, Adabi Darban, Muhammadiyah sebagai Gerakan Islam dalam Perspektif Historis dan Ideologis, Yogyakarta: LPPI UMY, 2002. 
PP. Muhammadiyah, "Keputusan Sidang Tanwir Muhammadiyah, tanggal 2528 Desember 1969 di Ponorogo tentang Chittah Perdjoangan Muhammadijah", Dokumen, Laporan dan Keputusan Sidang Tanwir, Yogyakarta, 1969.

-------, “Keputusan Mukatamar Muhammadiyah ke-38, tanggal 21-26 September 1971 di Ujungpandang, Dokumen, Yogyakarta, 1971.

PP. Muhammadiyah, Anggaran Dasar Muhammadiyah hasil Muktamar Muhammadiyah ke-41 di Surakarta, 1985.

PP. Muhammadiyah, Keyakinan dan Cita-cita Hidup Muhammadiyah, Yogyakarta: PP. Muhammadiyah, 1989.

Ricklefs, M. C., Sejarah Indonesia Modern, Yogyakarta: Universitas Gajah Mada, 1995.

Salam, Junus, KH. A. Dahlan, Amal, dan Perjuangannya, Jakarta: Depot Pengajaran Muhammadiyah, 1968.

Shihab, Alwi, Membendung Arus: Respon Gerakan Muhammadiyah terhadap Penetrasi Misi Kristen di Indonesia, Bandung: Mizan, 1998.

Sitompul, Einar Martahan, NU dan Pancasila, Jakarta: Sinar Harapan, 1989.

Sjoedja', H.M., Muhammadiyah dan Pendirinya, Yogyakarta: Majlis Pustaka PP. Muhammadiyah, 1989.

Suminto, Aqib, Politik Islam Hindia Belanda, Jakarta: LP3ES, 1985.

Syaifullah, Gerak Politik Muhammadiyah dalam Masyumi, Jakarta: Grafiti, 1997.

Yusuf, Slamet Effendy, et. al., Dinamika Kaum Santri: Menelusuri Jejak dan Pergolakan Internal NU, Jakarta: Rajawali, 1983. 